\title{
Gastric cancer during pregnancy with placental involvement: case report and review of published works
}

\author{
Seiya Oga', Masahiro Hachisuga', Nobuhiro Hidaka', Yasuyuki Fujita', Hiroshi Tomonobe ${ }^{1,2}$, \\ Hidetaka Yamamoto ${ }^{2}$, Kiyoko Kato ${ }^{1}$ \\ Departments of ${ }^{1}$ Obstetrics and Gynecology, ${ }^{2}$ Anatomic Pathology, Pathological Science, Graduate School of Medical Sciences, Kyushu University, \\ Fukuoka, Japan
}

Gastric cancer involving the placenta during pregnancy is rare; however, we present 1 such case in this report. A 31-year-old Japanese woman was referred at 26 weeks of gestation for the evaluation of a swollen left supraclavicular lymph node. Biopsy revealed poorly differentiated adenocarcinoma, and esophagogastroduodenoscopy with biopsy of the stomach confirmed the diagnosis of gastric cancer. Her epigastric and back pain became more pronounced and her general status worsened, and we performed a cesarean delivery at 29 weeks. Microscopic examination of the placental specimen revealed poorly differentiated adenocarcinoma cells diffused into the intervillous space. Postpartum chemotherapy consisted of S-1 plus oxaliplatin. Unfortunately, this treatment was ineffective, and the patient died 3 months after delivery. The infant did well, without clinical or laboratory manifestations of metastasis. In patients with advanced gastric cancer during pregnancy, it is important to perform a microscopic examination of the placenta to evaluate for metastatic involvement.

Keywords: Gastric cancer; Placental metastasis; Pregnancy; Villous invasion

\section{Introduction}

Women are increasingly becoming pregnant at older ages; therefore, it is predicted that the number of pregnant women with malignant disease will correspondingly increase. Gastric cancer during pregnancy is an uncommon condition, and placental metastasis is rare. Only 6 such cases have previously been reported [1-6]. The clinical characteristics of gastric cancer with placental metastasis are not completely understood. We present the case of a patient with gastric cancer diagnosed during pregnancy with placental metastasis. We have additionally presented a literature review to assess the clinical manifestations of this condition.

\section{Case report}

A 31-year-old primigravida with an unremarkable medical and family history was referred to our hospital at 26 weeks of gestation for the evaluation of a growing left supraclavicular lymph node that was suspected to be malignant lymphoma. She first noticed a cervical mass 2 weeks prior to her visit to our hospital. Her pregnancy had been uneventful, and she reported no digestive symptoms until 26 weeks of gestation.

Her examination revealed a swollen, hard, and immobile left supraclavicular lymph node. Biopsy of the node was performed, and histopathological examination revealed poorly differentiated adenocarcinoma with signet ring cells (Fig. 1A). Esophagogastroduodenoscopy revealed type 2 to 3 lesions extending from the upper and middle body to the angular incisure and antrum of the stomach. Biopsy of the gastric

Received: 2018.10.23. Revised: 2018.12.26. Accepted: 2019.01.22. Corresponding author: Nobuhiro Hidaka

Department of Obstetrics and Gynecology, Graduate School of Medical Sciences, Kyushu University, 3-1-1 Maidashi, Higashi-ku, Fukuoka 812-8582, Japan

E-mail: hidaka.nobuhiro.484@m.kyushu-u.ac.jp https://orcid.org/0000-0001-9854-3748

Articles published in Obstet Gynecol Sci are open-access, distributed under the terms of the Creative Commons Attribution Non-Commercial License (http://creativecommons. org/licenses/by-nc/3.0/) which permits unrestricted non-commercial use, distribution, and reproduction in any medium, provided the original work is properly cited.

Copyright (๑ 2019 Korean Society of Obstetrics and Gynecology 


\section{Obstetrics \& Gynecology Science}

Vol. 62, No. 5, 2019

tumor revealed that this lesion was histologically similar to the supraclavicular node, and a diagnosis of gastric cancer with metastasis to Virchow's node was confirmed. The serum carcinoembryonic antigen level at that time was $0.7 \mathrm{ng} / \mathrm{mL}$ (reference range $<5.0 \mathrm{ng} / \mathrm{mL}$ ).

After her biopsy, the patient's general status worsened, and her Eastern Cooperative Oncology Group performance status changed from 1 to 3 . She developed progressively worsening epigastric and back pain, requiring the use of opioid medications. Considering the comparatively mature gestational age of the fetus and her general condition, we decided to perform cesarean delivery and initiate chemotherapy soon after delivery. Labor induction for vaginal delivery was not attempted because of an unripe uterine cervix.

At 29 weeks of gestation, she delivered a male infant weighing 1,288 g, with Apgar scores of 8 and 9 at 1 and 5 minutes, respectively. No gross disseminated lesions were observed during surgery. However, microscopic examination of the placenta revealed poorly differentiated adenocarcinoma cells invading the intervillous space, with necrosis but without invasion of the villi (Fig. 1B). Histopathologically, we diagnosed placental metastasis of gastric cancer, and the final diagnosis was stage IV gastric cancer (CT3N3M1). There was no human epidermal growth factor receptor 2 expression. Thus, chemotherapy with S-1 plus oxaliplatin was initiated on the 7 th day postpartum.
Unfortunately, her cancer continued to spread, and metastases to multiple lymph nodes (left cervical, subclavian, axillary, and intraperitoneal) and the left-sided iliopsoas muscle were observed on performing computed tomography at 3 months postpartum. The patient died 3 months after delivery. The infant is doing well 8 months after birth, with no evidence of placental transmission of gastric cancer metastasis.

\section{Discussion}

The incidence of pregnancy complicated by malignant disease is low, with an estimated incidence rate of $0.02 \%$ to $0.1 \%[7,8]$. However, the mean age of pregnant women has been increasing; thus, the incidence rate of malignancy during pregnancy has increased. The most common malignancies occurring during pregnancy originate from femalespecific organs including the breast, uterine cervix, and the ovaries $[7,9]$. The other common malignancies observed during pregnancy include melanoma, lymphoma, and leukemia. Placental metastasis of maternal malignancies remains an uncommon condition. A study performed by Al-Adnani et al. [10] in 2007 reported that between 1930 and 2006, 75 patients presented with placental metastasis, including 18 with villous invasion. Malignant melanoma is the most
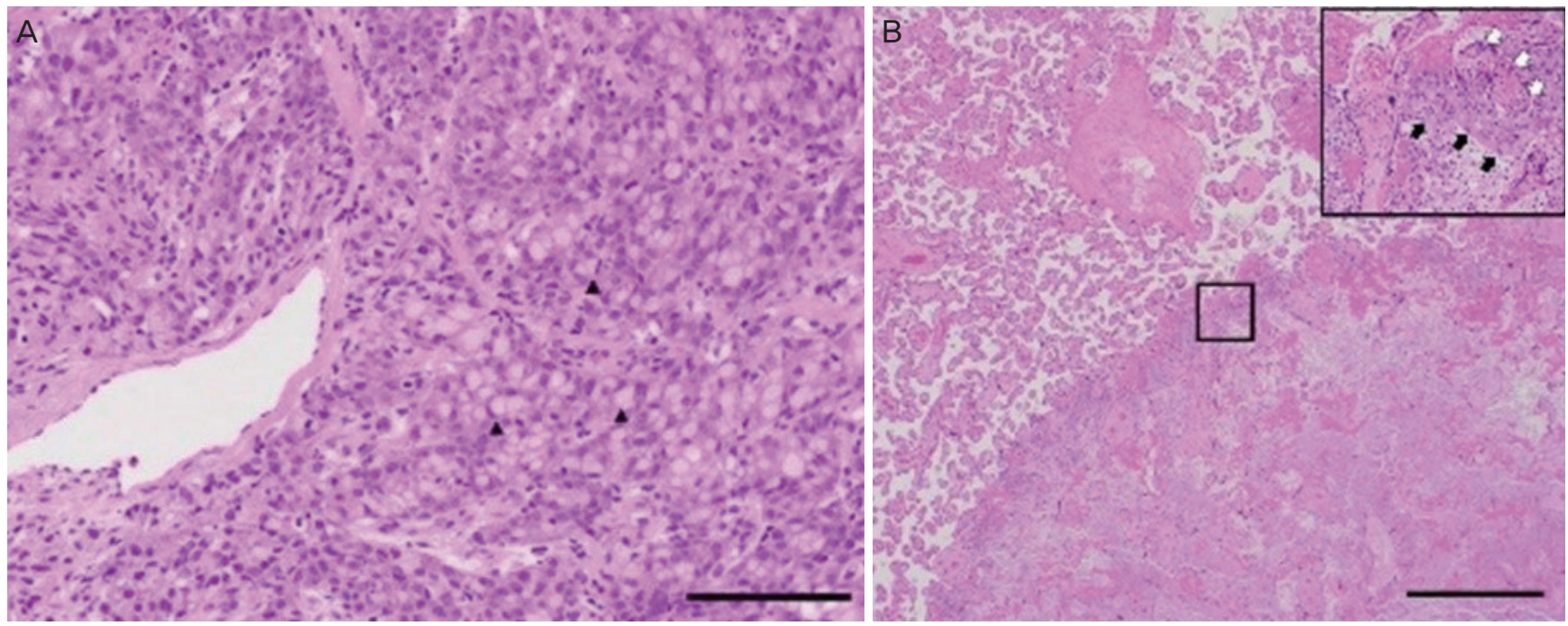

Fig. 1. Histopathological findings in specimens obtained in our patient showing the following: (A) Lymph node. Poorly differentiated adenocarcinoma cells with signet ring cells (arrow head) are observed. Stain: hematoxylin and eosin, scale bar: $100 \mu$ m. (B) Placental specimen. Carcinoma cells (black arrow) invading the intervillous space without invasion of the villi (white arrow) can be observed. Stain: hematoxylin and eosin, scale bar: $1 \mathrm{~mm}$. Squares indicate that the same lesion is pictured. 


\section{Obstetrics \& Gynecology Science}

Seiya Oga, et al. Placental involvement of gastric cancer

common metastatic maternal tumor, accounting for $30 \%$ of all placental metastases. Fetal metastasis was reported in 11 of these cases, with $50 \%$ of metastatic lesions originating from malignant melanoma. The syncytiotrophoblast layer of the placenta is the first barrier protecting the fetus from cancer invasion, and invasion of placental villi implies a high risk of fetal metastasis. The second barrier is tumor rejection by the fetal immune system. Fetal engraftment of maternal cancer cells is rare [7], although it may occur secondary to immaturity of the fetal immune system. Nearly all case reports describing fetal metastasis involve invasion of placental villi. In cases with maternal malignancy, it is important to evaluate the placenta using multiple sections.

An important clinical concern associated with placental metastasis is the possibility of fetal metastasis, which is not always obvious at birth. Vertical transmission of tumor cells typically becomes obvious 4 to 5 months after birth, and the clinical presentation may be observed from the time of birth to even 20 months after birth [11]. Routine examination of the placenta is warranted in patients with advanced cancer to assess the risk of fetal metastasis. If the placenta is free of metastatic disease, clinicians can reassure the parents that the risk of spread to the fetus is low. If the placenta is involved, the infant should be carefully evaluated for metastasis during the neonatal period and throughout infancy. Altman et al. [11] suggested that placental metastasis should be considered an indication of maternal stage IV disease and should be treated accordingly. Mothers should be carefully evaluated during the postpartum period and treated appropriately if placental metastasis is identified.

The incidence of gastric cancer is higher in elderly women, and only $0.1 \%$ of all cases of gastric cancer occur during pregnancy $[9,12]$. Although gastric cancer in pregnancy is rare compared with other malignancies, a few researchers have reported significantly high morbidity rates associated with this condition [12,13]. In 2009, Sakamoto et al. [13]

Table 1. Summary of studies (including the present case report) describing 7 patients with placental metastasis of gastric cancer

\begin{tabular}{|c|c|c|c|c|c|c|c|c|c|}
\hline Author & $\begin{array}{c}\text { Mater- } \\
\text { nal age } \\
\text { (yr) }\end{array}$ & $\begin{array}{c}\text { Primary symp- } \\
\text { toms }\end{array}$ & $\begin{array}{c}\text { GA at } \\
\text { diagno- } \\
\text { sis (wk) }\end{array}$ & $\begin{array}{c}\text { GA at } \\
\text { delivery } \\
\text { (wk) }\end{array}$ & $\begin{array}{l}\text { Mode of } \\
\text { delivery }\end{array}$ & Histology & $\begin{array}{l}\text { Villous } \\
\text { inva- } \\
\text { sion }\end{array}$ & $\begin{array}{l}\text { Ma- } \\
\text { ternal } \\
\text { status }\end{array}$ & $\begin{array}{l}\text { Neonatal } \\
\text { outcome }\end{array}$ \\
\hline $\begin{array}{l}\text { Khatib et } \\
\text { al. [1] }\end{array}$ & 26 & $\begin{array}{l}\text { Lower } \\
\text { abdominal and } \\
\text { back pain }\end{array}$ & 26 & 31 & $\mathrm{CS}$ & $\begin{array}{l}\text { Poorly differentiated } \\
\text { adenocarcinoma }\end{array}$ & None & Dead & $\begin{array}{l}\text { Alive and } \\
\text { well at } \\
9 \text { months }\end{array}$ \\
\hline $\begin{array}{l}\text { Baker et } \\
\text { al. [2] }\end{array}$ & 22 & $\begin{array}{l}\text { Rapidly } \\
\text { increasing } \\
\text { abdominal } \\
\text { girth }\end{array}$ & 28 & 28 & $\mathrm{CS}$ & $\begin{array}{l}\text { Undifferentiated } \\
\text { infiltrating carcinoma } \\
\text { with scattered signet } \\
\text { cells }\end{array}$ & None & Dead & $\begin{array}{l}\text { Alive and } \\
\text { well at } \\
18 \text { months }\end{array}$ \\
\hline $\begin{array}{l}\text { Miller et } \\
\text { al. [3] }\end{array}$ & 35 & $\begin{array}{l}\text { Vomiting, } \\
\text { diarrhea, } \\
\text { and upper } \\
\text { abdominal pain }\end{array}$ & 28 & 30 & $\mathrm{CS}$ & $\begin{array}{l}\text { Poorly differentiated } \\
\text { adenocarcinoma }\end{array}$ & None & Dead & $\begin{array}{l}\text { Alive and } \\
\text { well at } \\
12 \text { months }\end{array}$ \\
\hline $\begin{array}{l}\text { Chen et } \\
\text { al. [4] }\end{array}$ & 35 & $\begin{array}{l}\text { Occasional } \\
\text { nausea and } \\
\text { epigastric pain }\end{array}$ & 34 & 34 & $\mathrm{CS}$ & $\begin{array}{l}\text { Intermediate } \\
\text { differentiated } \\
\text { adenocarcinoma }\end{array}$ & Positive & Alive & $\begin{array}{l}\text { Alive and } \\
\text { well at } \\
6 \text { months }\end{array}$ \\
\hline $\begin{array}{l}\text { Jeong et } \\
\text { al. [5] }\end{array}$ & 37 & Epigastric pain & 21 & 23 & $\begin{array}{c}\text { TOP } \\
\text { (hysterotomy } \\
\text { and subtotal } \\
\text { hysterectomy) }\end{array}$ & $\begin{array}{l}\text { Poorly differentiated } \\
\text { adenocarcinoma }\end{array}$ & None & Dead & Stillbirth \\
\hline $\begin{array}{l}\text { Wang et } \\
\text { al. [6] }\end{array}$ & 35 & $\begin{array}{l}\text { Occasional } \\
\text { headaches }\end{array}$ & 34 & 34 & $\mathrm{CS}$ & $\begin{array}{l}\text { Poorly differentiated } \\
\text { adenocarcinoma }\end{array}$ & Positive & Dead & $\begin{array}{l}\text { Alive and } \\
\text { well at } \\
19 \text { months }\end{array}$ \\
\hline $\begin{array}{l}\text { Current } \\
\text { case } \\
\text { report }\end{array}$ & 31 & $\begin{array}{l}\text { Swelling of left- } \\
\text { sided cervical } \\
\text { lymph node }\end{array}$ & 27 & 29 & $\mathrm{CS}$ & $\begin{array}{l}\text { Poorly differentiated } \\
\text { adenocarcinoma }\end{array}$ & None & Dead & $\begin{array}{l}\text { Alive and } \\
\text { well at } \\
10 \text { months }\end{array}$ \\
\hline
\end{tabular}

The previously reported 6 studies ( 6 patients)+the present case report ( 1 patient)=7 patients.

GA, gestational age; CS, cesarean section; TOP, termination of pregnancy. 


\section{Obstetrics \& Gynecology Science}

Vol. 62, No. 5, 2019

reviewed the literature describing Japanese patients with gastric cancer during pregnancy and observed that $92.5 \%$ of the patients were diagnosed with advanced-stage cancer. The 1- and 2-year survival rates were $18.0 \%$ and $15.1 \%$, respectively. Placental involvement is rare and has been described in $<5 \%$ of the reported cases of gastric cancer during pregnancy $[1,2,10]$. The English language literature comprising cases reported between 1980 and 2017 describes only 6 patients with placental metastasis of gastric cancer [1-6]. Table 1 summarizes these case reports, as well as details regarding our patient. The gestational age at the time of diagnosis ranges from 21 to 34 weeks (median 28 weeks). All patients were diagnosed at an advanced stage of the cancer. The main symptom was abdominal pain; however, some patients complained of headache or lymphadenopathy (as was observed in our patient). Notably, 6 infants were born alive and did well, and 2 of them showed placental villous invasion. To date, no case reports have described fetal metastasis. The histopathological types of gastric cancer that are known to have metastasized to the placenta are poorly differentiated adenocarcinoma in 5, undifferentiated signet-ring cell carcinoma in 1, and moderately differentiated adenocarcinoma in 1 case. Despite treatment, 7 of 8 mothers died after delivery.

We decided to perform preterm cesarean delivery at 29 weeks of gestation in our patient. Balancing the risk to mother and fetus, some researchers recommended that surgical intervention with chemotherapy following delivery can be initiated without delay if the gestational age is $>28$ weeks [13]. Usually, termination of pregnancy is recommended if gastric cancer is diagnosed at an early stage of pregnancy. The optimal management strategy for cases diagnosed between 22 and 27 weeks remains controversial. Chemotherapy is a possible choice, although it is associated with the risk of teratogenicity in the early stages of pregnancy. Other considerations affect the mid stage of pregnancy, including the dosing of anticancer agents. Although pharmacokinetic changes occur during pregnancy, no recommendation is available for optimal dosing of chemotherapy. The usual recommendation is to use the standard dose with reduction if blood toxicity occurs. Another consideration is the potential for chemotherapy induced fetal adverse effects. Anticancer drugs are transferred to the fetus through the placenta and possibly cause fetal adverse effects, such as bone marrow suppression. After the mother has received anticancer treat- ment, depending on the timing of delivery, the fetus may be at risk for complications such as myelosuppression and increased vulnerability to infection, in addition to the usual risks of preterm delivery [14].

We encountered a rare case of gastric cancer during pregnancy with placental involvement. Routine examination of the placenta is warranted in patients with advanced gastric cancer to assess the risk of fetal metastasis.

\section{Conflict of interest}

No potential conflict of interest relevant to this article was reported.

\section{Patient consent}

The patient provided informed consent for the publication and the use of their images.

\section{References}

1. Khatib F, Shaya M, Samueloff A. Gastric carcinoma with metastasis to the placenta and amniotic fluid: case report and review of the literature. Eur J Obstet Gynecol Reprod Biol 2003;107:208-9.

2. Baker AM, Haeri S, Shafer A, Moldenhauer JS. Maternal gastric carcinoma metastatic to the placenta. Eur J Obstet Gynecol Reprod Biol 2010;153:225-6.

3. Miller K, Zawislak A, Gannon C, Millar D, Loughrey MB. Maternal gastric adenocarcinoma with placental metastases: what is the fetal risk? Pediatr Dev Pathol 2012;15:237-9.

4. Chen Y, Li Y, Wang H, Lu J, Jin M, Zhang Z. Maternal gastric carcinoma with metastasis to the placenta: $A$ case report. Oncol Lett 2014;8:2509-10.

5. Jeong B, Shim JY, Kim CJ, Won HS, Lee PR, Kim A. Massive perivillous fibrin deposition in the placenta and uterine metastasis of gastric adenocarcinoma during pregnancy. J Obstet Gynaecol Res 2014;40:1150-3.

6. Wang H, Lu J, Wei P, Zhang M, Wang X, Zhang Z. Maternal gastric carcinoma without gastrointestinal symptoms. Int J Gynaecol Obstet 2015;128:273-4. 


\section{Obstetrics \& Gynecology Science}

Seiya Oga, et al. Placental involvement of gastric cancer

7. Pavlidis NA. Coexistence of pregnancy and malignancy. Oncologist 2002;7:279-87.

8. Pentheroudakis G, Pavlidis N. Cancer and pregnancy: poena magna, not anymore. Eur J Cancer 2006;42:12640.

9. Massad LS, Einstein MH, Huh WK, Katki HA, Kinney WK, Schiffman M, et al. 2012 updated consensus guidelines for the management of abnormal cervical cancer screening tests and cancer precursors. Obstet Gynecol 2013;121:829-46.

10. Al-Adnani M, Kiho L, Scheimberg I. Maternal pancreatic carcinoma metastatic to the placenta: a case report and literature review. Pediatr Dev Pathol 2007;10:61-5.

11. Altman JF, Lowe L, Redman B, Esper P, Schwartz JL,
Johnson TM, et al. Placental metastasis of maternal melanoma. J Am Acad Dermatol 2003;49:1150-4.

12. Lee HJ, Lee IK, Kim JW, Lee KU, Choe KJ, Yang HK. Clinical characteristics of gastric cancer associated with pregnancy. Dig Surg 2009;26:31-6.

13. Sakamoto K, Kanda T, Ohashi M, Kurabayashi T, Serikawa $T$, Matsunaga $M$, et al. Management of patients with pregnancy-associated gastric cancer in Japan: a minireview. Int J Clin Oncol 2009;14:392-6.

14. Esposito S, Tenconi R, Preti V, Groppali E, Principi N. Chemotherapy against cancer during pregnancy: a systematic review on neonatal outcomes. Medicine (Baltimore) 2016;95:e4899. 